\title{
気液二相乱流の超音波モニタリング*
}

\author{
村井 祐一**, 田坂 裕司 ${ }^{* * *}$, 朴 炫珍***
}

\section{Ultrasonic Monitoring of Gas-liquid Two-phase Turbulent Flows}

\author{
Yuichi Murai, Yuji Tasaka and Hyun Jin Park
}

\section{1. 緒 論}

超音波による流動計測の最大の利点は，不透明な管路 や不透明な流体の外側から内部流動を可視化できること である，超音波の送受信器は，それらの外部に設置する ことが出来るので非接触計測となる。ゆえに工業用とし ての実用性が高く, 40 年以上の開発史をもつ.レー ザーやX 線や中性子線などといった厳格な安全管理は 不要で，しかもポータブルである。つまり依頼があれば, 全ての必要器材をスーツケース 1 つに入れて出発し, 現 場に着いたら，しばらくの音響環境の調整をすれば計測 を開始することが出来る。計測データは全てリアルタイ 厶で取得され，あとから結果を吟味するのではなく，そ の場で結果を判断できる。従って流動パラメター調査な どの作業上の自由度が高い。計測対象にもよるが, 典型 的な出カレートは $10 \mathrm{~Hz}$, 計測長は $1 \mathrm{~m}$, 空間分解能は $0.5 \mathrm{~mm}$ といったところである. 超音波の基本周波数を 変化させれば上記の条件は大幅に変更できる ${ }^{1)}$.

超音波による流れのモニタリングは，例えば，何百万 個と普及している伝搬時間差式の超音波流量計が知られ る.これに対してエネルギー施設・化学プラント用の特 殊仕様の超音波ドップラー流量計はいまも開発途上であ る.もともと超音波の利用は, 構造材料の探傷用を初め とした静止物体の非破壊検查や，人体組織など準静止物 体の超音波エコーイメージングで普及した。 しかし対象 が流れで，かつ気液界面を含むときには，超音波の性質 を最大利用した高度で高速な信号処理技術を要する2-4). 時間と空間の両方の分解能を最大化し, 界面の複雑変形 と流速分布の関係を同時に捕らえなければならない。

\section{2. 二相流における超音波の応答}

超音波を利用するとき，有効に活用すべきはその直進 性にある。ゆえに超音波をビーム状に絞って線計測を実

* 原稿受付 2019 年 6 月 5 日

** 北海道大学 工学研究院 エネルギー環境システム部門 （テ060-8628 札幌市北区北 13 条西 8 丁目, E-mail :murai@eng.hokudai.ac.jp)

*** 北海道大学 工学研究院 エネルギー環境システム部門 （テ 060-8628 札棍市北区北 13 条西 8 丁目）
現することができる．このとき発生する超音波の波長 $\lambda$ が，対象物を捕らえる空間分解能を決める. Fig. 1 は気 液二相流における様々に存在する界面の代表長さ $L$ と $\lambda$ の関係を図示したものである ${ }^{5)} . L / \lambda \gg 1$ ならば鏡面 反射を生じ，相手が気相であれば位相を反転させた超音 波が反射される。 $L / \lambda \ll 1$ ならば拡散反射が生じ，相手

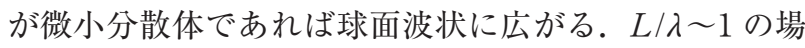
合は指向性をもつ反射となり, 加えて $L / \lambda=1 / 4$ ならば 最大の後方散乱強度をもつ。

入射した超音波と流体中から反射してきた超音波の間 で検知できる量は, 全部で 3 つある (Table 1 参照). 1 つめは飛行時間差 $(\mathrm{ToF})$ で, そこから反射体や反射 面の位置がわかる，位置が既知の場合は流体中の音速が わかる. 2 つめは反射波の振幅 (Echo Intensity) で, その情報から反転体の大きさとそれを構成する物質の硬 度（音響インピーダンス＝密度と音速の積）を推定する

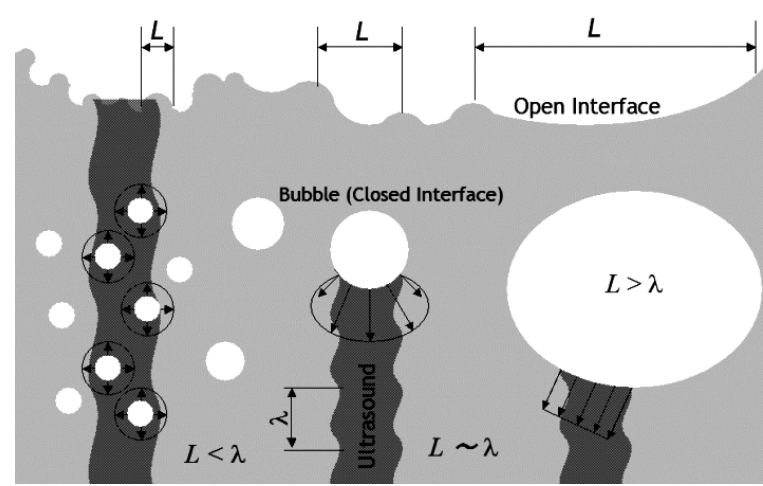

Fig. 1 Various responses of ultrasound at interfaces.

Table 1 Nine patterns of signal processing.

\begin{tabular}{|c|c|c|c|}
\hline \multirow{2}{*}{$\begin{array}{l}\text { Information detected } \\
\text { from reflection wave } \\
\text { of ultrasound pulse }\end{array}$} & \multicolumn{3}{|c|}{ Length scale of interface $L$, relative to basic wavelength of ultrasound, $\lambda$} \\
\hline & $L<\lambda$ & $L \sim \lambda$ & $L>\lambda$ \\
\hline $\begin{array}{l}\text { Time of flight } \\
\text { (Phase) }\end{array}$ & $\begin{array}{l}\text { Phase is conserved for } \\
\text { closed interface like a } \\
\text { bubble, and is reversed } \\
\text { for opened interface. }\end{array}$ & \begin{tabular}{|ll} 
Phase depends & on \\
surface tension & (or \\
rigidity of interface).
\end{tabular} & $\begin{array}{l}\text { Phase is reversed } \\
\text { due to kinematically } \\
\text { free boundary. }\end{array}$ \\
\hline $\begin{array}{l}\text { Echo intensity } \\
\text { (Amplitude) }\end{array}$ & $\begin{array}{l}\text { Being weakened by } \\
\text { diffused reflection. } \\
\text { (Rayleigh scattering) }\end{array}$ & $\begin{array}{l}\text { Heterogeneous reflection } \\
\text { due to interference. } \\
\text { (Mie scattering) }\end{array}$ & $\begin{array}{l}\text { Being kept with } \\
\text { mirror reflection. }\end{array}$ \\
\hline $\begin{array}{l}\text { Doppler information } \\
\text { (Frequency) }\end{array}$ & $\begin{array}{l}\text { Moving velocity of } \\
\text { interface modifies the } \\
\text { frequency of reflection } \\
\text { wave. }\end{array}$ & $\begin{array}{l}\text { Moving velocity of } \\
\text { interface modifies the } \\
\text { frequency of reflection } \\
\text { wave. }\end{array}$ & $\begin{array}{l}\text { Significant Layer of } \\
\text { local standing wave } \\
\text { is generated to erase } \\
\text { Doppler shift. }\end{array}$ \\
\hline
\end{tabular}




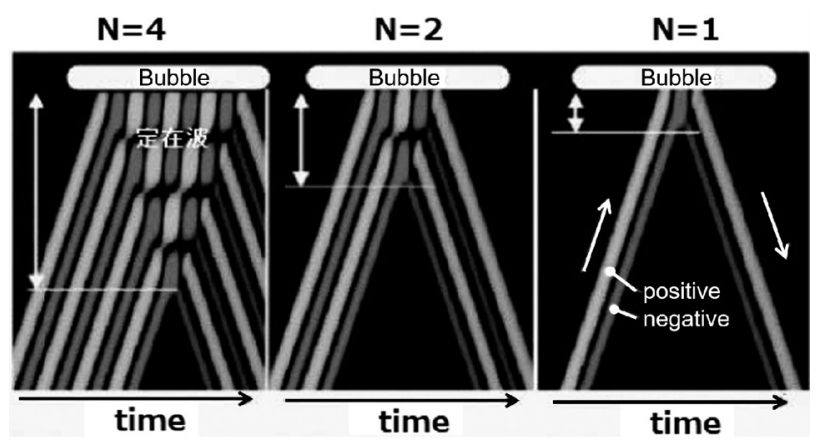

Fig. 2 Reflection of ultrasound pulse at gas surface.

ことが出来る，さらには，反射波の位相から対象物が気 体か固体かを識別できる，例えば，固体壁面にわずかに 気膜があるときは，その厚みが数ミクロンであっても， 位相の反転として明確に現れる．3つめは反射波の周波 数の変化であり, ドップラーシフト理論から反射体の移 動速度が判る。超音波ドップラー流速分布計 (UVP: Ultrasound Velocity Profiler) は, 微小なトレーサ粒子 の運動から，流体の速度分布を求める手法として普及し た。な拀，微小粒子が運動していても平滑な気液界面近 傍ではドップラーシフトは生じない吕。それは気液界面 で入射波と反射波が重なり局所的な定在波を形成するた めである (Fig. 2 参照)。この性質を利用すると周波数 が不変となる位置を検出することで気液界面の位置と形 状を特定することができる。

\section{3. ボイド率の計測}

気液二相流におけるボイド率を超音波で計測しょうと するとき，以下の 2 つの方法がある.

(1) バルクボイド率の計測

二相流の混合音速の理論から, 発信器と受信器の間の 平均ボイド率が得られる。すなわちボイド率 $a$ と音速 $c$ の関係を記述する次式を使う。

$$
c=\min \left\{c_{L}, \sqrt{\frac{p}{\alpha(1-\alpha) \rho_{L}}}\right\}, \alpha<0.5
$$

ここで $p$ は系の静圧， $\rho_{L}$ は液体の密度， $c_{L}$ は液体の音 速である，ただし混合音速理論の前提として，対象とす るボイド率の定義長は，分散性二相流として近似性が保 たれるよう計測線上に多数の（少なくとも 10 個以上の） 気泡や気液界面が存在しなければならない。それが少な い場合は，式(1)の值のまわりで大きく分散する．また反 射波の先頭部で気泡体積の固有振動に伴う振動や，波動 の分散性に伴うプリカーサーが伝播する7). 換言すれば, これらの情報を取り出すことで気泡サイズ分布を統計的 に推定することができ，その技術は超音波スペクトロス コピーとして知られる。

\section{（2）ボイド率の空間分布の計測}

気泡の数密度, あるいは気液界面積濃度が高いと, 超 音波は最初の界面で最大反射し，その奥には伝播しにく

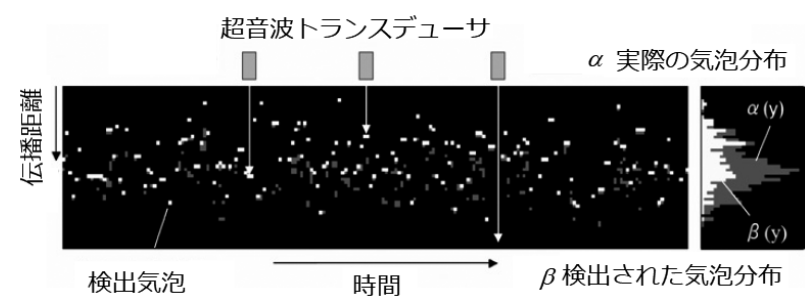

Fig. 3 Void fraction profiling by ultrasonic pulse.

い。このような場合では，使える信号は最初の反射波だ けとなる。しかし超音波パルスの送受信を高速に繰り返 す制御により，最初の反射波のみで全体のボイド率分布 を復元することが可能となる。

Fig. 3 は，発信と受信を一体とする超音波トランス デューサの利用時の，気泡検出の概念図である．多数の 気泡のうちトランスデューサに最も近い気泡（白で表 現）が検知される。これをあるサンプリング時間で統計 した気泡分布を距離 $y$ の関数 $\beta(y)$ とするとき, 真のボ イド率分布 $\alpha(y)$ は，次式の関係をもつ.

$$
\alpha(y)=\beta(y)\left(1-\frac{1}{\delta} \int_{0}^{y} \beta(y) d y\right)^{-1}
$$

ここで $\delta$ は $y$ 方向のデータの空間サンプリング波長で ある.この式は統計学的に誘導されるもので8), 流れの 状態には無関係である。

実施例として，Fig. 4 に水槽内の散気管からのエア レーションに扔ける水平線上のボイド率の計測結果を示 す．容器の外部から，5秒間（サンプル数は 100）の平 均ボイド率分布が計測できた。個々の気泡は，反射波の 周波数分布で検出し，その位置は飛行時間差から特定さ れる。この時間積分值を式(2)で変換し，水槽内のボイド 率分布を得る。リアルタイム処理が可能な程度に演算負 荷が小さいので，移動平均法を使えば， 5 秒間の移動平 均ボイド率分布を 0.1 秒刻みで連続的にモニタリングで きる。

同じ方法を，船舶の空気潤滑における乱流境界層内の ボイド率分布計測に利用した。その結果を Fig. 5 に示 す。空気潤滑とは, 多数の微細気泡を境界層内に注入し, 気泡と乱流渦の干渉を発生させて壁面に作用する摩擦抵 抗を低減する技術で，船舶の省エネ技術として過去 15 年の間に急速に普及が拡大している9 。その技術に打け る命題は, 最大レイノルズせん断応力となる位置にいか

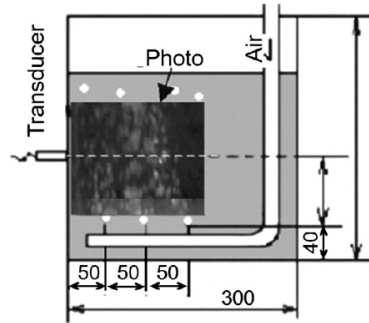

(a) Aeration chamber

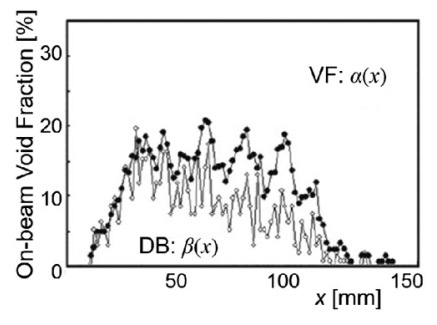

(b) Void fraction profile
Fig. 4 Void fraction profiling in an aeration chamber. 


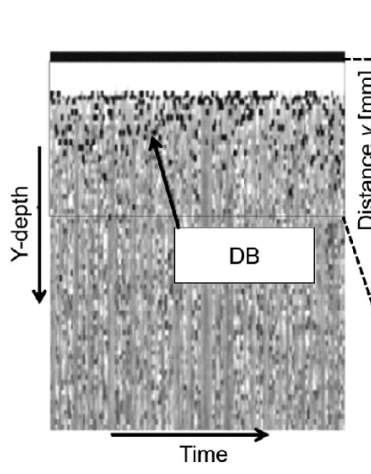

(a) Bubble detection

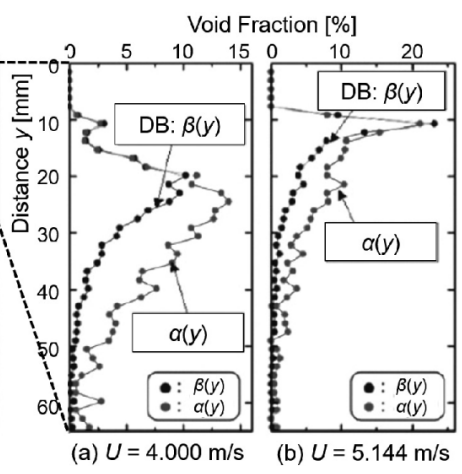

(b) Void fraction profiles
Fig. 5 Void fraction profiling in ship surface lubrication.

に気泡を集中させることが出来るかである，同図の左に あるプロットで黒い点が超音波で検出された気泡である. ここから累積分布 $\beta(y)$ を計算し，ボイド率 $\alpha(y)$ に変換 したところ，同図右 2 つの結果となった。すなわち船速 Uが増加するとボイド率 $\alpha(y)$ のピーク位置が壁面に接 近することが判った．気泡の乱流拡散と乱流渦による気 泡の集積効果のバランスが船速 Uによって変化するこ とを示す重要な結果となった。

\section{4. 気液界面分布の計測}

前節では気泡流を対象とした局所瞬時平均としてのボ イド率分布の計測事例を挙げた。これに対して気液二相 流には，層状分離流，プラグ流，スラグ流，チャーン流， それに液膜流などがある。これらの気液界面の位置や形 状を外部から非接触で計測できないかという技術相談は, 著者のグループに毎年何件も入ってくる.

Fig. 6 は直径 $40 \mathrm{~mm}$ の水平円管内の空気・水のスラ グ流を超音波で計測した例である，気液界面は，そこか らの反射波の周波数変動で検知することができた．高速 度カメラ撮影との同期計測によりその誤差は概ね, 超音 波の液体中に抢ける 2 波長（1 mm）以内であった。液
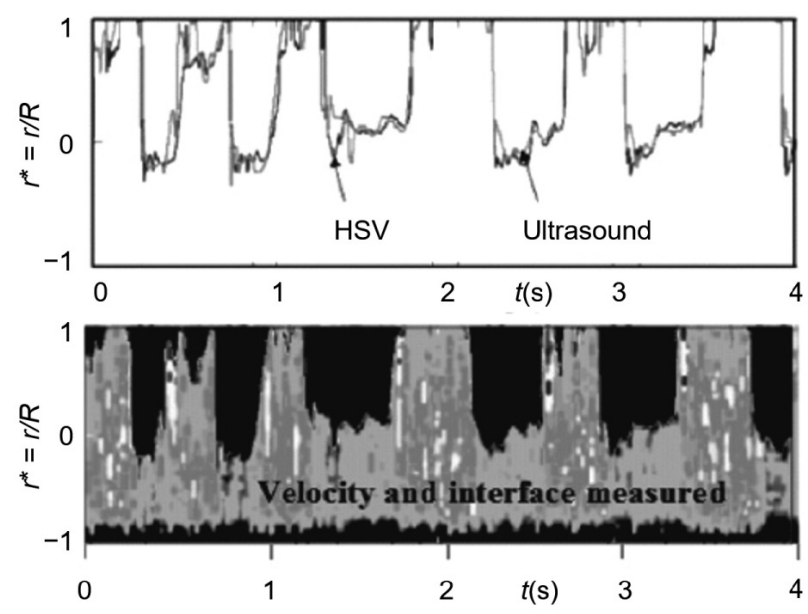

Fig. 6 Gas-liquid slug flow in a horizontal pipe. Top: detected interface, bottom: liquid velocity distribution.

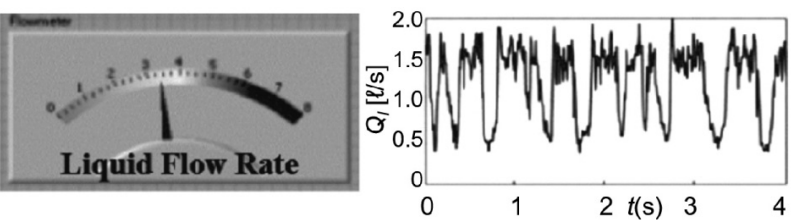

Fig. 7 Instantaneous flow rate of liquid phase in the slug flow.

相中ではドップラーシフト周波数から内部の流速分布を 得た。これを積分することで Fig. 7 に示すようなスラ グ流の瞬時体積流量が得られる。気液二相流では流量変 動が常に存在するため, 単相流の流量計とは異なり, 時 間分解型の流量計の開発が要となっている。なお円管に 対して超音波の計測線を1つだけしか使わないときは, 流量計測のために一定の積分モデルが必要となる．著者 らのグループでは，超音波トランスデューサを 3 個配置 すれば，殆どの気液二相流パターンに対して流量計測誤 差が $5 \%$ 以内に収まることを実験的に示した ${ }^{10)}$.

\section{5. 気泡と液膜の計測}

移動する気液界面をより高解像度で計測するにはどう すべきか. 個々の気泡の形状や，固体と気体の間の液膜 の計測においては，流速が大きいほど高い時間分解能の 超音波信号処理が必要となる ${ }^{11)}$ 。この場合は，超音波を 振幅と周波数で代表するのではなく，その原形となる波 形の解析が可能となるようなシステムを構成する.

Fig. 8 は，固体壁面近傍を移動する気泡に対して，超 音波パルスの反射波を検知した例である。同図(a)のよ うに一定の肉厚をもつ固体壁面の外側に超音波トランス デューサを設置し，その反対側に打いて液体中に気泡が 流れる。このとき同図(b)のように，気泡の有無によっ て反射波に差異が生まれる。気泡なしの場合でも，固体 壁面と液体の間の界面で反射波が発生するが，気泡あり の場合では，その反射波の振幅が拡大寸る。これは気体 の音響インピーダンスが液体より何桁も小さいため, 超 音波が全反射の状態に近づくためである。しかし振幅が 拡大したことだけでは，単に，気泡の有無しか判定でき

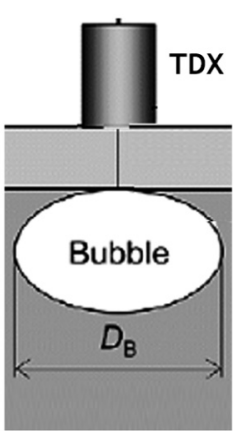

(a) Sensing situation

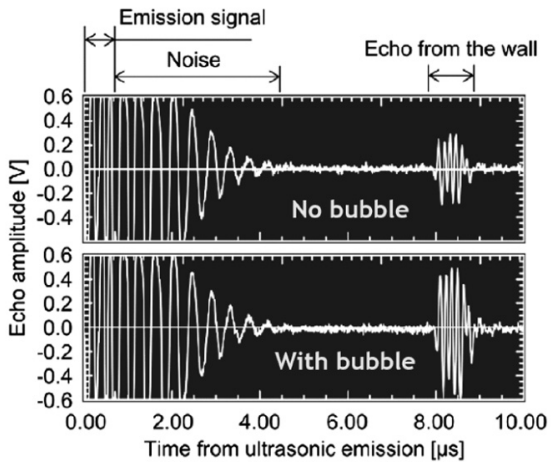

(b) Difference of echo due to bubble
Fig. 8 Detection of bubbles moving in wall proximity. 


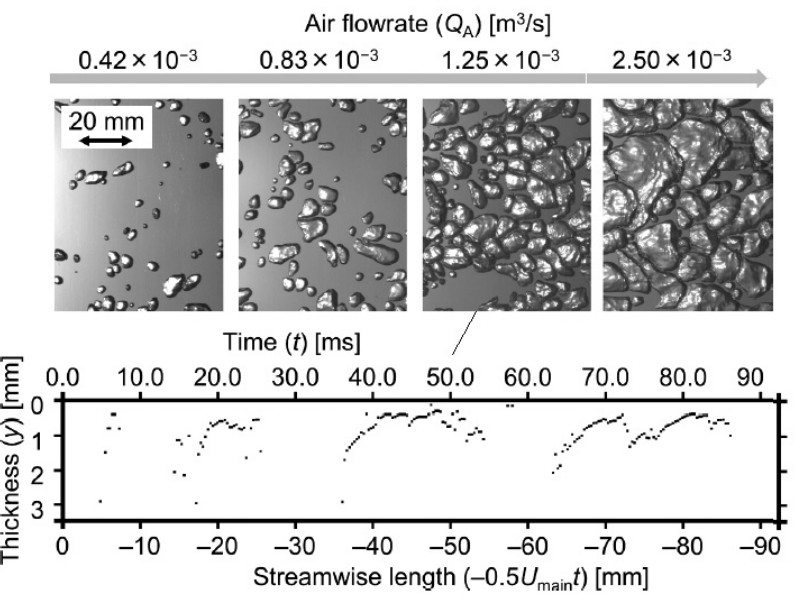

Fig. 9 Measurement of liquid film thickness covering the bubbles suspended inside turbulent boundary layer of a ship.

ない．気泡がない状態の反射波との間で差分波形をとる ことで，多くの情報を抽出することができる ${ }^{12)}$ ．特に超 音波パルスを構成する最初の 1 山の波形のピーク位置か ら，気泡界面の位置を特定することが出来る，その分解 能は超音波の液体中に打ける波長の $1 / 10$ 程度となる.

Fig. 9 は, 平底の船舶の直下を流れる気泡界面の分布を 計測した事例である。船速は $U=3 \mathrm{~m} / \mathrm{s}$ で，超音波パル スの送受信周波数は $3 \mathrm{kHz}$ とした。このとき距離換算 された流れ方向の空間分解能は $1 \mathrm{~mm}$, その垂直方向の 空間分解能は 50 ミクロンとなる。この結果から, 空気 潤滑法による乱流摩擦抵抗低減が生じる条件では, 固体 壁面と気泡の間に 500 ミクロン程度の液膜が常に残存す ることが判明した，この液膜厚さは乱流境界層のバッ ファー層厚さと同程度であることから，大きな気泡は対 数域にある慣性支配域とバッファー層以内の粘性支配域 の間の運動量交換を遮断する役割があることが説明され た ${ }^{13)}$.また，界面波形を注視すると乱流渦変動に伴う微 細振動が見られる。すなわち, 大気泡の変形能が乱流せ 儿断応力を作る秩序構造を吸収している過程が可視化さ れた。

\section{6. 三相流以上の流れの可視化}

外部から非接触で混相流の内部流動を可視化できると いう特徵は，産業上の複雑な流体システムや，あるいは 自然界の流れの理解にむけた研究で, 様々な要望に発展 している．以下に 2 つの例を挙げる.

（1）水・油・ガスの管内三相流

原油パイプラインやシェールガス輸送，それに深海エ アリフトポンプなどでは不混和な 2 液体に加えてガスが 混在するような三相流を扱う。いずれも圧力損失の最小 化だけでなく，極端な脈動の制御を主要な課題としてい る。脈動の発生原因は, 混相流のダイナミクスにあり, その解明と抑制または活用が求められている。このよう な背景から, 著者らは水・油・空気の管内三相スラグ流
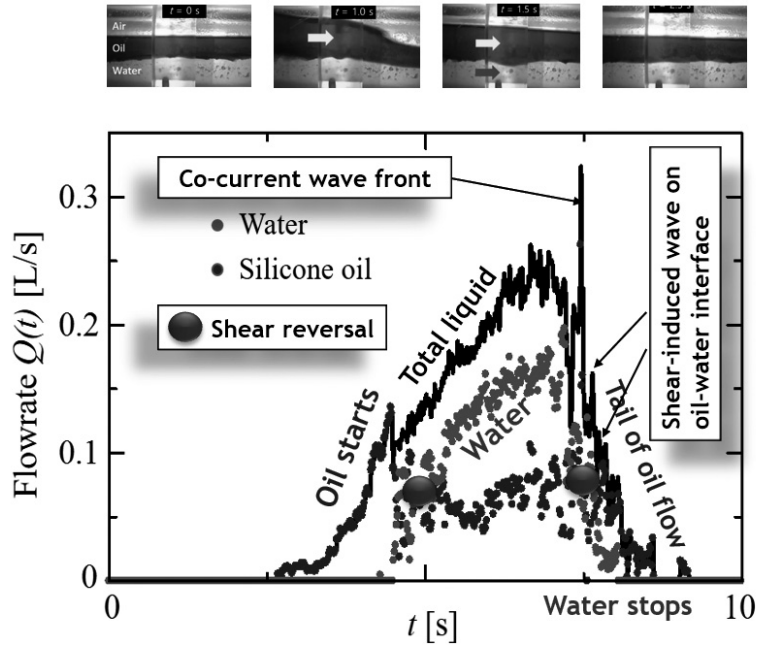

Fig.10 Time-resolved constitutional flow rates of air-oilwater three phase slug flow in an inclined pipe.

の内部構造を捕らえるような超音波による可視化試験を 実施した。その一例を Fig.10に示す．円管内径は 50 $\mathrm{mm}$ で, 重いほうから順に水, シリコン油(動粘度は 10 $\mathrm{cSt})$, 空気が成層し, それが変形して三相のスラグ流が 発生する. 同図はスラグ 1 回の通過を時間分解して，水 と油の瞬時体積流量の変動, およびその和である液体全 体の体積流量を計測した例である ${ }^{14)}$ 。この結果から, 液 体全体の和の流量変動波形は大きく 1 山であるのに対し て, 水と油は異なる構成で相別の内部流量変動をもつこ とが判明した，具体的には，三相スラグ流の先頭では油 が先に鋭い立ち上がりで通過し, その後, 水が加速して 油が減速する．2つの液相の瞬時流量が内部で逆転する ということは，水と油の間で作用する運動量交換の方向 が逆転することを意味する．すなわち三相スラグ流の内 部では応力分布が反転するという事象が発生する．スラ グ後半では水からせん断応力を受けて再加速した油が, 臨界フルード数に到達し, 水と一緒に研波する。この結 果, その波面に伴いパルス状の瞬間最大流量を記録する. その後はある振動数を伴った減衰振動とともに両相の流 量がゼロに近づく．な掞低粘度条件では水と油が相互分 散してエマルジョン状態になるが，その際には混合音速 理論での推定のほか, 静電容量卜モグラフィ（ECT） を併用した相分布計測 ${ }^{15)}$ で，さらに確度を向上させる開 発も行っている16).

(2) 乱泥流の内部流動の可視化

海洋物理学に扔いて乱泥流（turbidity current）は50 年を越えても未だ説明できない現象の一つである．僅か な濃度の粒子懸濁流が海水中で $500 \mathrm{~km}$ というスケール で水平に伝播する現象である。与えられた位置エネル ギーと想定される乱流エネルギー散逸の二者から計算さ れる伝播距離より 2 桁近く大きいためである。その謎は 乱泥流の内部構造にあるとして世界中で CFD による説 明が試みられている。しなし不透明であるゆえ実験的な 


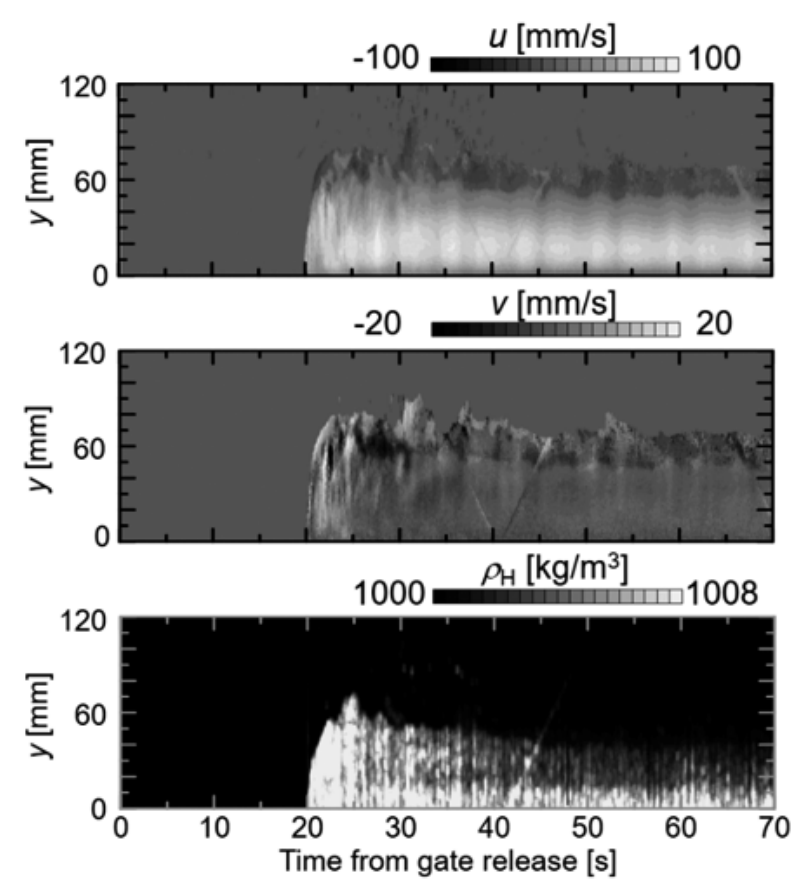

Fig.11 Ultrasonic visualization of turbidity current driven by particulate layer in quiescent water.

検証と仮説の立証が実現していない。著者らは実験的な モデルによる解明について, 海洋研究開発機構 (JAMSTEC) から依頼を受け，スイス連邦工科大学 ローザンヌ校 (EPFL) の実験設備を使って試験した。 その結果の一例を Fig. 11 に示す. 粒子は 1 ミクロン程 度のケイ素で, その懸濁液は水より僅か $0.8 \%$ だけ高い 状態を設定した。同図で $u$ と $v$ は 2 つ超音波卜ラン スデューサを設定することで取得した水平方向と垂直方 向の粒子懸濁液の流速成分である。これらは超音波の ドップラーシフト周波数から取得されたものである. 加 えて微粒子からの超音波の反射強度から, 微粒子の濃度 分布を推定することができる(理論があるが省略).す なわち, 超音波だけで乱泥流の内部 2 次元流速分布と懸 濁液の密度分布を得ることが出来た. 同図では時間結果 を右向きとしているので, 乱泥流が左に進行していると してその空間構造を解釈する。この結果, 乱泥流の先頭 部では粒子の上方巻き上げがあり，それが下流でも沈降 せず長距離にわたり持続することが判った。このとき乱 泥流の内部で二段階の密度層を形成し, 水相とあわせる と三相の安定成層を作ることが見出された。つまり乱泥 流は 2 つの密度界面をもち, 上の界面は絶対速度がゼロ となる位置に, 下の界面は最大速度となる位置におよそ 符合した。さらに, 速度分布 $(u, v)$ からレイノルズせん 断応力を求めた結果, 2 つの密度界面の間では負の值を とり乱泥流に滑り作用を与えることも判明した。 これら が組み合わさり, 乱泥流それ自体の位置エネルギーの低 下と系全体のエネルギー散逸の最小化が同時に発生し, 長距離にわたる自己持続性を生んでいると解釈するに 至った。

\section{7. 結 言}

超音波がもつ特性を利用して, 混相流の内部流動の定 量的なモニタリングを実現した事例について紹介した。 この技術の特徴は，高速流動する界面をもつ流れを時間 分解して捕らえることにあり，そこが材料探傷や医療用 の超音波技術と大きく異なる。 また，高濃度混相流に対 しては, 光学的な可視化が不可能な点で, 超音波利用の 優位性は自明である。今後はさらに高時間分解，高空間 分解されたシステムを設計し，超音波送受信素子の多次 元配列化を進めることで, 現在の PIV 技術のような高 いデー夕密度を出力するシステムに近づけることができ よう。その結果，超音波計測による実測データ駆動型の R\&D スキームが確立されると見达まれる。データが十 分に高密度に得られる場合には CFD とのデータ同化や 流体基礎方程式の併用 ${ }^{17)}$ も可能となり, 新たなアプロー チが派生する。

本稿では取り上げていないが, 超音波による流れの可 視化技術は，二相流だけでなく液体金属 ${ }^{18)}$ や泥状物質 ${ }^{19)}$,

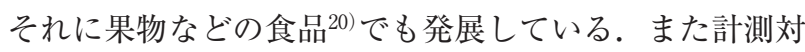
象からその内部の組成分布や速度分布をモニタリングす るだけでなく，物性分布に広げることも可能で超音波レ オメトリーの開発も急展開している $21-23)$. 将来的には透 明な流路を使った可視化試験は不要になり，世界中の PIV ユーザー達が超音波にシフトする時代が近づいて いるかも知れない. 可視化情報学会に設置されている UVP 研究会（主査：木倉先生（東工大), 幹事 : 村川先 生 (神戸大)）では，今まさにこの議論をしているとこ ろである.

\section{参考文献}

1) Takeda, Y. (ed.): Ultrasonic Doppler Velocity Profiler for Fluid Flow, Springer (2012).

2 ) Suzuki, Y., Nakagawa, M., Aritomi, M., Murakawa, H., Kikura, H., Mori, M.: Microstructure of the flow field around a bubble in counter-current bubbly flow, Exp. Thermal \& Fluid Sci., Vol.26 (2002) pp.221-227.

3 ) Murakawa, H., Kikura, H., Aritomi, M.: Measurement of liquid turbulent structure in bubbly flow at low void fraction using ultrasonic Doppler method, J. Nuclear Sci. \& Tech., Vol.40 (2003) pp.644-654.

4) Murakawa, H., Kikura, H., Aritomi, M.: Application of ultrasonic Doppler method for bubbly flow measurement using two ultrasonic frequencies, Exp. Thermal \& Fluid Sci., Vol.29, No.7 (2005) pp.843-850.

5 ) Murai, Y., Tasaka Y., Nambu Y., Takeda Y., Gonzalez A.S.R. Ultrasonic detection of moving interfaces in gas-liquid twophase flow, Flow Meas. \& Inst., Vol.21 (2010) pp.356-366.

6 ) Murai, Y., Fujii, H. Tasaka, Y., Takeda, Y.: Turbulent bubbly channel flow investigated by UVP, J. Fluid Sci. \& Tech., Vol.1 (2006) pp.12-23.

7 ) Egashira, R., Yano, T., Fujikawa, S.: Linear wave propagation of fast and slow modes in mixtures of liquid and gas bubbles, 
Fluid Dyn. Res., Vol.34 (2004) pp.317-334.

8 ) Murai, Y., Ohta, S., Shigetomi, A., Tasaka, Y., Takeda, Y.: Development of an ultrasonic void fraction profiler, Measurement Sci. \& Tech., Vol.20 (2009) 114003.

9 ) Murai, Y.: Frictional drag reduction by bubble injection, Exp. Fluids, Vol.55 (2014) 1773.

10) Gonzalez, S.R., Murai, Y,, Takeda, Y.: Ultrasound based gasliquid interface detection in gas-liquid two phase flows, Adv. Chem. Eng., Vol.37 (2009) pp.1-27.

11) Park, H.J., Tasaka, Y., Oishi, Y., Murai, Y.: Drag reduction promoted by repetitive bubble injection in turbulent channel flows, Int. J. Multiphase Flow, Vol.75 (2015) pp.12-25.

12) Park, H.J., Tasaka, Y., Murai, Y.: Ultrasonic pulse echography for bubbles traveling in the proximity of a wall, Measurement Sci. \& Tech., Vol.26 (2015) 125301.

13) Park, H. J., Tasaka, Y., Murai, Y.: Bubbly drag reduction investigated by time-resolved ultrasonic pulse echography for liquid films creeping inside a turbulent boundary layer, Exp. Thermal \& Fluid Sci., Vol.103 (2019) pp.66-77.

14) Hitomi, J., Murai, Y., Park,H.J., Tasaka, Y.: Ultrasound flowmonitoring and flow-metering of air-oil-water three-layer pipe flows, IEEE Access, Vol.5, No.1 (2017) pp.15021-15029.

15) Tan, C., Liu, W., Dong, F., Murai, Y.: Dispersed oil-water twophase flow measurement based on pulse-wave ultrasonic Doppler coupled with electrical sensors, IEEE Trans. Instrumentation \& Measurement, Vol.67, No. 9 (2018) pp. 2129-2132.

16) Shi, X., Tan, C., Dong, F., Murai, Y.: Oil-gas-water three-phase flow characterization and velocity measurement based on time-frequency decomposition, Int. J. Multiphase Flow, Vol.111 (2019) pp.219-231.
17) Tiwari, N., Murai, Y., Tasaka, Y., Pressure field estimation from ultrasound Doppler velocity profiler for vortex-shedding flows, Flow Measurement \& Instrumentation, Vol.67 (2019) pp. $23-32$.

18) Akashi, M., Yanagisawa, T., Tasaka, Y., Vogt, T., Murai, Y., Eckert, S.: Transition from convection rolls to large-scale cellular structures in turbulent Rayleigh-Benard convection in a liquid metal layer, Phys. Rev. Fluids, Vol.4, No.3 (2019) 033501.

19) Yoshida, T., Tasaka, Y., Tanaka, S., Park, H.J., Murai, Y.: Rheological properties of montmorillonite dispersions in dilute $\mathrm{NaCL}$ concentration investigated by ultrasonic spinning rheometry, Appl. Cray Sci., Vol.161 (2018) pp.513-523.

20) Yoshida, T., Tasaka, Y., Park, H.J., Murai, Y., Teramura, H., Koseki, S.: Inner structure visualization of fresh fruits utilizing ultrasonic velocity profiler, J. Visualization, Vol.21 (2018) pp. 253-265.

21) Tasaka, Y., Yoshida, T., Rapberger, R., Murai, Y.: Linear viscoelastic analysis using frequency-domain algorithm on oscillating circular shear flows for bubble suspensions, Rheologica Acta, Vol.57 (2018) pp.229-240.

22) Tasaka, Y., Kimura, T., Murai, Y.: Estimating the effective viscosity of bubble suspensions in oscillatory shear flows by means of ultrasonic spinning rheometry, Exp. Fluids, Vol.56 (2015) 1867.

23) Yoshida, T., Tasaka, Y., Murai, Y.: Efficacy assessments in ultrasonic spinning rheometry: linear viscoelastic analysis on non-Newtonian fluids, J. Rheology, Vol.63, Issue 4 (2019) 5086986 . 